MARTELOTTA, Mário Eduardo. (2011) Mudança linguística: uma abordagem baseada no uso. São Paulo: Cortez, 136 págs.

Resenhado por Maria Célia LIMA-HERNANDES (Universidade de São Paulo) e Maria Angélica FURTADO DA CUNHA (Universidade Federal do Rio Grande do Norte)

\title{
A NATUREZA DA MUDANÇA NAS LÍNGUAS NATURAIS
}

e prestarmos atenção ao modo como as pessoas idosas falam, perceberemos diferenças marcantes com relação à linguagem dos mais jovens. Partindo do fato incontestável de que as línguas mudam com o passar do tempo, este livro tem como objetivo fornecer aos leitores iniciantes nos estudos sobre a mudança linguística um conjunto de conhecimentos acerca dos mecanismos e das motivaçóes envolvidos na mudança por que passam as línguas naturais.

As mudanças linguísticas ocorrem de forma mais acentuada, mais acelerada ou lenta sempre em função das situações reais de interação entre pessoas. Regióes urbanas, cujo ritmo de vida é mais acelerado, demonstram a dinamicidade das relaçóes estabelecidas entre os cidadãos e, em consequência, a dinamicidade da língua. A velocidade que se imprime à dinâmica social afeta sobremaneira os usos linguísticos, fazendo com que novos padrôes de usos emerjam e instaurem novas regras variáveis na língua. A fim de analisar a mudança e a variação, o autor desse livro, Mário Edurado Martelotta, faz uma incursão pelos movimentos teóricos da linguística, desde o século XIX, com a gramática histórico-comparativa, passando por Saussure e Chomsky, até os dias de hoje, com as abordagens linguísticas centradas no uso.

A complexidade do jogo comunicativo é discutida por Martelotta, que tece uma exposição bem alinhavada das abordagens sobre mudança. Esse material constitui-se como um compêndio que registra os avanços científicos ocorridos desde o século XX, quando se deu maior ênfase, de um lado, ao formalismo voltado para a sintaxe autônoma, e de outro, ao funcionalismo calcado no impacto linguístico provocado pelas diferenças sociais. Recuando ao século XIX, encontramos ideias linguísticas que nos fazem pensar se o que 
vemos hoje ocorrendo na descrição de abordagem funcionalista não seria um passo seguinte àqueles. Quando Martelotta convida o leitor a pensar sobre a evoluçẫo linguística num quadro em que esteja integrado o interlocutor e a situação, parece querer abrir mais um parágrafo à introdução do livro de Herman Paul, neogramático que teve a coragem de afirmar que forças psíquicas e forças físicas precisam receber a devida atenção do linguista.

Sob a visão tradicional da gramática normativa, somos levados a pensar que a interação comunicativa entre as pessoas que falam a mesma língua se dá com base em um conjunto de regras gramaticais regulares e estáveis, que se mantêm por um certo período de tempo, e que fornecem aos falantes meios para a formação e compreensão das frases da sua língua. Essa visão estática da língua se contrapóe à concepção de língua como um organismo maleável, dinâmico, que se adapta às necessidades cognitivas e comunicativas de seus usuários, como defendem as correntes teóricas mais recentes da linguística.

Portanto, o papel das interaçóes será fundante na inserção de um novo modo de olhar para a língua em uso, sem dicotomias, sem oposiçóes categóricas, sem sistemas (ou subsistemas) autônomos. Esse novo olhar da mudança em processo exige habilidades e conhecimentos provenientes dos vários subsistemas (fonologia, morfologia, discurso) porque a sintaxe passa a ser nesse novo século o locus do output, da produção de dados significativos que permitem resgatar as pistas da língua-processo. Lidar com a mudança linguística depois dos avanços nas ciências diversas que resvalam na língua e na linguagem, tais como a cognição e a psicologia, torna, assim, a tarefa do linguista ainda mais complexa. As relaçóes entre os falantes revelam-se um emaranhado complexo de informaçóes revestidas das intençóes desses mesmos interlocutores num recorte espaço-temporal específico, que seguramente reflete o continuum histórico dessas relações humanas.

O que esse livro de Martelotta nos permite ver é que há uma evolução linguística, sim, mas, a par dela, encontra-se em curso também uma evolução do pensamento linguístico. Se os comparativistas priorizaram o léxico, os neogramáticos passam a olhar de forma especial para a fonética; se os estruturalistas priorizaram a morfologia, os gerativistas condensam a massa de estudos na sintaxe. Em todos esses espaços de pensamento estiveram presentes funcionalistas, que se perguntaram o tempo todo sobre o papel do ouvinte, do interlocutor, mas não puderam ouvir o eco suficiente de seus questiona- 
mentos. Por assim dizer, cada período de evolução do pensamento é matizado pelo sabor funcionalista, que desloca para o centro da atenção o papel do outro, a intenção de quem fala tendo em vista a figura de seu interlocutor, as incompreensóes e objetivos, a bagagem discursivo-pragmática de cada um dos interlocutores. Esse sabor da alteridade veio pela mão de muitos que deram um tempero especial às dicotomias conferindo-lhes a liga necessária. E essa liga permitiu repensar a natureza de uma língua plena em dinamicidade.

Num histórico bem desenhado das abordagens teóricas sobre mudança, Martelotta recua ao século XIX para resgatar pontos comuns entre o trabalho neogramático e o trabalho funcionalista. Evidencia que os grandes neogramáticos tiveram sua formação na Alemanha, e atuaram em grandes universidades de lá, dentre as quais aparece Leipzig, que foi foco do movimento neogramático. De lá, parte para o estruturalismo de Saussure para romper com suas dicotomias, que já foram um avanço significativo para a época de sua proposição. Repartir em dois blocos o que antes nem se vislumbrava separar foi, sim, um grande passo para o que hoje presenciamos na ciência linguística.

E seguindo essa nobre intenção de apresentar um quadro o mais completo possível das grandes escolas, Martelotta passeia por alguns pilares da teoria gerativista, pontilhando os contatos possíveis entre esse modelo e o funcionalista. Depois, visita a sociolinguística laboviana para demonstrar a relevância das ambiguidades no processo de mudança. Essa é uma parada obrigatória no roteiro de viagem que o autor produz porque é justamente a ideia de variação e usos sociais que possibilitará na paisagem o surgimento de uma nova estação: a mudança a partir de dados reais. É essa nova estação do percurso histórico que vai favorecer o reconhecimento da suma importância do papel da interação e da cognição para lidar com elementos que revestem a informação, tais como a compreensão do outro e de suas intençóes (antecipação da bagagem pragmática do interlocutor), em cuja base está o exercício inferencial. As próximas estaçóes são como uma paisagem vista pela janela: move-se ao sabor da sincronia. É nessa paisagem que se discutem construçôes bem como gramaticalização e seus princípios.

Nesse volume, Martelotta aborda questóes pertinentes à mudança linguística tal como elas foram formuladas ao longo da história da ciência linguística, focalizando conceitos e procedimentos metodológicos formulados por linguistas de paradigmas distintos, com o objetivo de descrever e inter- 
pretar os processos de mudança das línguas, em seus diferentes níveis de análise. Vem atender, primeiramente, a uma demanda daqueles que se interessam por mudança linguística e que precisam compreender a dinâmica não só do material linguístico, mas também do pensamento científico no momento de maior ebulição linguística: período que vai do século XX ao XXI. Destina-se, portanto, a estudantes de graduação, de pós-graduação e a professores e pesquisadores que têm interesse nesse campo da ciência linguística. Destina-se a quem quer aprender, a quem quer ensinar.

E para ser coerente com a ideia de que a língua segue uma dinâmica sem ponto final, Martelotta produz, com toda a coerência que lhe é peculiar, a ligação necessária entre o ponto de partida e de chegada desse roteiro de viagem: a língua muda porque os falantes interagem em situações diversas e nelas buscam a intercompreensão o tempo todo. É a sintaxe limando os usos linguísticos continuamente.

Em suma, Princípios básicos da mudança linguistica: uma abordagem baseada no uso é um livro que se compóe de três capítulos. No primeiro, intitulado A natureza dinâmica das linguas, constrói-se a compreensão do fenômeno da mudança linguística por meio da apresentação das abordagens teóricas sobre a mudança desde o século XIX (comparatistas e neogramáticos) até o século XX (estruturalistas, gerativistas e sociolinguistas). No capítulo segundo, intitulado Linguistica centrada no uso e mudança, a discussão é pautada pela relação existente entre biologia e cultura, abrindo portas para tratar do papel da interação e da cognição nos usos linguísticos. Essas reflexôes desembocarão, como era de se esperar, em temas como a regularidade da mudança e processos inferenciais implicados, que se orientam pelo conhecimento prévio dos falantes (de aspectos da língua e do mundo). Nesse quadro, discute-se a conformação sintática de construções. No capítulo terceiro, especializado na discussão de gramaticalização e lexicalização, Martelotta, rompendo com mais essa dicotomia, discute princípios e motivaçóes que permitem configurar esses processos. Para finalizar o volume, além das consideraçóes finais, que sintetizam as discussóes do livro, o autor apresenta: (i) possíveis desdobramentos do tema da mudança linguística, indicando ao leitor o mais eficiente caminho para aprender a 'enxergar' a mudança numa abordagem centrada no uso: observando e analisando dados. Essa orientação é a chave para reconhecer a dinâmica da língua; (ii) indicaçóes de leituras associadas ao tema da mudança. 
Essa obra de Martelotta consubstancia-se, enfim, como um generoso convite a todo aquele que se interesse pela evolução das reflexóes humanas sobre sua mais complexa habilidade comunicativa: a língua.

Recebido em: 28/03/2013 Aprovado em: 26/08/2013 